ANDRZEJ MADEJA (Toruń)

\title{
Suwerenność państwa w koncepcji integracyjnej Roberta Schumana
}

I. Robert Schuman (1886-1963) słusznie zaliczany jest to do grona europejskich „ojców założycieli”, czyli wąskiej grupy polityków, którzy w sposób czynny i bezpośredni uczestniczyli w powoływaniu Wspólnot Europejskich ${ }^{1}$. Użyczył on integracji nie tylko swego nazwiska ${ }^{2}$, ale był w jej powstawanie osobiście zaangażowany. Jego wkład objął nie tylko formułowanie teoretycznych postulatów integracji, lecz również kształtowanie treści rozwiązań instytucjonalnych nowych organizacji. Możemy przyjąć, iż poglądy prezentowane przez Schumana stanowią ciekawy obiekt analiz nie tylko ze względu na ich szczególną treść, lecz także z powodu ich praktycznej doniosłości. Przedstawiwszy krytykę status quo Schuman nie wyraził wprost, jak jego zdaniem wyglądać winna właściwa formuła suwerenności. Zarysował natomiast wizję współpracy, realizacja której miała doprowadzić do docelowego ukształtowania suwerenności państwa w pożądany przez niego sposób. Tym samym preferowany przez Schumana obraz suwerenności wpisany został w jego koncepcję integracyjną.

II. Jako zwolennik neotomizmu wyznawał Schuman pauliańską koncepcję władzy pochodzącej od Boga. Dlatego naród, jako podstawowa i naturalna wspólnota ludzka stanowiąca jedyne źródło władzy w porządku do-

${ }^{1}$ Szerzej o kategorii „ojców założycieli”: Les pères de l'Europe: cinquante ans après, red. P.-F. Smets, Bruylant, Bruxelles 2001; C.G. Anta, Les pères de l'Europe, P. Lang, Bruxelles 2007; Robert Schuman et les Pères de l'Europe, red. S. Schirmann, P. Lang, Bruxelles 2008.

${ }^{2}$ Mamy tu na myśli tzw. Deklarację Schumana z 1950 r. Jej faktycznym autorem był J. Monnet, zaś Schuman zgodził się przedstawić ów dokument publicznie 9 V 1950 r., czyniąc w ten sposób jego treść oficjalnym stanowiskiem rządu francuskiego. Deklarację, która stanowiła punkt wyjścia dla powołania Europejskiej Wspólnoty Węgla i Stali, słusznie postrzega się w kategoriach symbolicznego początku procesu integracji wspólnotowej. Szerzej: M.T. Bitsch, Robert Schuman et la Declaration du 9 mai 1950, [w:] Les pères de l'Europe..., s. 55-68; Le Plan Schuman dans l'histoire. Intérêts nationaux et projet européen, red. A. Wilkens, Bruylant, Bruxelles 2004. 
czesnym, zawsze pozostawał w centrum jego myśli ${ }^{3}$. Podstawą Europy były dlań narody zorganizowane w państwa. Określał je mianem „historycznej rzeczywistości”, zaś dzielące je granice polityczne i etniczne postrzegał jako wynik procesu dziejowego ${ }^{4}$. Można przypisać Schumanowi umiarkowaną, ale niezmienną afirmację płaszczyzny narodowej ${ }^{5}$. Zwykł uznawać, że granice są „,godne szacunku”, zaś „dobrze pojęty patriotyzm jest wyrazem miłości bliźniego" ". Neotomistyczne aksjomaty prowadziły do dwóch wniosków. Władza miała swe pochodzenie od czynnika metafizycznego, ale sprawowana winna być per populum, czyli zgodnej ze standardami demokracji, opierającej się na równości i godności człowieka. „Demokracja jest permanentnie zagrożona przez przeciwieństwo indywidualizmu, którym jest faktyczna niezależność, zagrażającą całkowitym bezwładem albo nastaniem anarchii”". Jednym z przykładów takiej niezależności jest władza suwerenna: to antytetyczna relacja między chrześcijańską demokracją a le républicanisme populaire i la nationalisme intégral ${ }^{9}$. Drugą implikacją były założenia w duchu pluralizmu i subsydiarności. W okresie międzywojennym krytykował Schuman jakobiński centralizm i wewnętrzną homogeniczność państwa narodowego. Nie był jednak zwolennikiem autonomii, którą postrzegał jako fundowanie „państwa w państwie”. Republika była dlań jedna i niepodzielna, co nie znaczyło, że musiała być uniforme. Reprezentował zatem regionalizm serieux et judicieux, określając Lotaryngię jako ma petite patrie ${ }^{10}$. Tym samym suwerenność w perspektywie narodowej stawała się kategorią niezbędną, ale o ściśle określonym wymiarze i celu. Służyła mianowicie powiązaniu płaszczyzny la petite patrie (patria propria) z szerszym i wyższym szczeblem ogólnonarodowym (patria communis) ${ }^{11}$. Stanowiło to pogląd sprzeczny nie tylko z koncepcjami autokratycznymi, lecz także z tradycją francuską wyrosłą z wydarzeń roku $1789^{12}$. Schuman zaczął usuwać ,ideologiczne ru-

${ }^{3}$ Idem, French Foreign Policy (29 X 1953), [za:] A.S. Milward, The European Rescue of the Nation-State, Routledge, London 2000, s. 329.

${ }^{4}$ R. Schuman, Dla Europy, Znak, Kraków 2009, s. 24.

${ }^{5}$ F. Roth, Robert Schuman. Du Lorrain des frontières au père de l'Europe, Fayard, Paris 2008, S. 533.

${ }^{6}$ R. Schuman, Dla Europy..., s. 24.

${ }^{7}$ Idem, List H. Hartmanna, [w:] J. Wahl, Robert Schuman. Ojciec Europy, Wokół Nas, Gliwice 1995 , s. 13.

${ }^{8}$ Idem, Est-il trop tard pour faier l'Europe?, [w:] Quelle Europe?, Centre Catholique des intellectueles Français, Paris 1958, s. 223.

${ }^{9}$ R. Mougel, Schuman et la philosophie politique de Jacques Maritain, [w:] Robert Schuman - Homme d'Etat, citoyen du Ciel, red. R. Clément, E. Husson, OEIL, Paris 2006, s. 90-91.

${ }^{10}$ C. Pennera, Robert Schuman. La jeunesse et les débuts politiques d'un grand européen, de 1886 à 1924, Pierron, Paris 1985.

${ }^{11}$ E. Husson, L'Amité de Robert Schuman et de Konrad Adenauer, [w:] Robert Schuman Homme d'Etat..., s. 36-37.

${ }^{12}$ R. Mougel, op. cit., s. 92. 
iny $[\ldots]$, zamiast o państwie, mówił o społeczeństwie, zamiast o Francji o Francuzach"13.

Dla zrozumienia poglądu na zewnętrzny aspekt suwerenności ważne są słowa wypowiedziane 21 III 1953 r. w Moguncji:

„Ważniejsza jest dla nas logika zdarzeń niż logika pojęć. [...] Pojęcia nie są czymś absolutnym; wywodzą się one bowiem od konkretów i powstają drogą abstrakcji. Tak się też ma rzecz z pojęciem suwerenności [...] Prawnie zagwarantowana niezależność jest pojęciowym postulatem każdego suwerennego państwa. Polityka interesuje jednak głównie ustalenie, czy i w jakim stopniu jedno państwo jest gospodarczo lub politycznie zależne od innego państwa, i to w sytuacji, gdy działa w interesie własnego bezpieczeństwa lub własnej gospodarki. To jest kwestia stwierdzenia pewnych faktów"14.

Wszystkie problemy, przed jakimi stanęły państwa po II wojnie, wymykały się autonomicznej kontroli politycznej i ekonomicznej ${ }^{15}$. Środki, którymi dysponowało każde z państw były niewystarczające dla zaspokojenia jego potrzeb $^{16}$. Własna siła nie była skutecznym zabezpieczeniem dla narodu ${ }^{17}$. Autarkia była nierealna i niewykonalna. Izolacja stała się źródłem słabości, a wręcz przyczyną upadku ${ }^{18}$. W rezultacie pełną niezależność uznał Schuman za niedające się uzasadnić roszczenie ${ }^{19}$. „Niepodległość stawać się będzie w coraz większej mierze pojęciową fikcją" ${ }^{20}$. Dostrzegał anachroniczność ówczesnych państw, które jawiły się dla niego twierdzami gotowymi na odparcie ataku. Wiosną $1951 \mathrm{r}$. określił wprost istniejący system państw narodowych mianem „anachronizmu”, „herezji” i „nonsensu”21. Krytycznie odnosił się jednak nie do państw narodowych in genre, ale do modelu geopolitycznego opartego na hegemonii i egoizmie ${ }^{22}$. W kategoriach największego zagrożenia postrzegał głębiej usytuowany problem, za jaki uważał nacjona-

${ }^{13}$ J. Lecanuet, Wyprzedzając spokojnym krokiem swoja epokę, [w:] Chrześcijański Demokrata i Europejczyk, Wokół Nas, Gliwice 1991, s. 113-114.

${ }_{14}$ R. Schuman, Przemówienie w Moguncji (21 III 1953). www.cvce.eu. Wszystkie wystąpienia przywołane w artykule bez wskazania źródła pochodzą z tego serwisu internetowego. Data dostępu 23 XI $2011 \mathrm{r}$.

${ }^{15}$ R. Schuman, Dla Europy..., s. 22.

${ }^{16}$ Ibidem, s. 19; idem, Comment le français d'aujourd'hui peut-il concevoir l'Europe?, Société de Papeterie et d'Imprimerie de Grenelle, Paris 1951, s. 4.

${ }^{17}$ R. Schuman, Dla Europy..., s. 21.

${ }^{18}$ Ibidem, s. 19, 31.

${ }^{19}$ Ibidem, s. 25.

${ }^{20}$ R. Schuman, Przemówienie w Moguncji (21 III 1953).

${ }^{21}$ Idem, Comment..., s. 4; idem, Otwarcie konferencji poświęconej negocjacjom nad Europejska Wspólnota Obronna (15 II 1951), s. 2.

${ }^{22}$ H. Brugmans, Trwate dzieło, [w:] Robert Schuman: Chrześcijański..., s. 103; A. Muñoz, L'engagement européen de Robert Schuman, [w:] Robert Schuman et les Pères..., s. 50-51. 
lizm, czyli realizację egoizmu na poziomie narodowym ${ }^{23}$. Jego przejawem był protekcjonizm państwowy, partykularyzm oraz zgubne dążenie do autarkii ${ }^{24}$, „czyniące z Europy bezkrwistą społeczność, która sama zakuwa się w kajdany i leży w agonii" 25 . Uzupełnieniem poglądu o wysokim stopniu współzależności było uznanie istnienia katalogu obiektywnych reguł współistnienia państw, obowiązek przestrzegania których wynikał z samego faktu członkostwa we wspólnocie międzynarodowej ${ }^{26}$.

III.1. Schuman był zdania, że Europa nie może być zlepkiem rywalizujących ze sobą państw, „lecz wspólnotą działania zaplanowanego i zorganizowanego w sposób wolny"27. W opisie form współpracy posługiwał się terminami ,zjednoczenie”, „spójność” i „,koordynacja”28. Niezależnie od formy podstawowym jej warunkiem była równorzędność partnerów. Współpraca międzyrządowa była niezbędna i pożyteczna, o ile nie przypisywało jej się siły ani skuteczności, gdyż te nie były jej udziałem. Jej istnienie miało raczej charakter symboliczny niż rzeczywisty ${ }^{29}$. Jak wyraził to sam Schuman: $B e-$ fore anything effective could be done, the dogma of national sovereignty had to be breached ${ }^{30}$. Kryterium oceny nie stanowiła dla niego kwestia, czy forma współpracy dawała się pogodzić z paradygmatem suwerenności. Kluczowym pytaniem było, ,czy i w jakim zakresie powinienem w danych okolicznościach zrezygnować z części suwerenności”31. Proces ograniczania dokonywać miał się zatem poprzez zawieranie traktatów, na drodze negocjacji ich postanowien $^{32}$. Przy tym do rangi zasadniczej perspektywy ocennej urastały konkretne warunki i wyzwania, przed jakimi stało państwo. Dla opisu takiej formy współpracy Schuman posługiwał się terminem ,integracja”, przez który rozumiał „organiczne i trwałe zespalanie tego, co kiedyś było niezależne"33. Integracja zachodziła na drodze unifikacji szeregu sfer aktywności państw w niej uczestniczących ${ }^{34}$. Stąd możemy przyjąć, iż różnica między integracją a zwykłą współpracą miała charakter zarówno jakościowy (ograniczenie suwerenności), jak i ilościowy (zakres przedmiotowy). Schuman wprost od-

${ }^{23}$ F. Roth, op. cit., s. 201-202.

${ }^{24}$ R. Schuman, Comment..., s. 4.

${ }^{25}$ P. Werner, Spotkanie osobiste, [w:] Robert Schuman: Chrześcijański..., s. 48.

${ }^{26}$ R. Schuman, The Spirit of the Treaty (6 IX 1951), „Vital Speeches of the Day” [dalej: „VSD”] t. XVII, 1951, nr 24, s. 747.

${ }^{27}$ Idem, Dla Europy..., s. 61.

${ }^{28}$ Ibidem, s. 18.

${ }^{29}$ Ibidem, s. 69, 91; R. Schuman, Comment ..., s. 9.

${ }^{30}$ Idem, France and Europe, „Foreign Affairs” t. XXXI, 1953, nr 3, s. 351.

${ }^{31}$ Idem, Przemówienie w Moguncji (21 III 1953).

${ }^{32}$ Idem, French Foreign Policy..., s. 329.

${ }^{33}$ Idem, European Integration. Obstacles and Progress (11 VI 1954), „VSD” t. XX, 1965, nr 20, s. 616.

${ }^{34}$ Ibidem, s. 618. 
rzucał abstrakcyjne modele, oparte na teorii i odzwierciedlające marzenia. Podkreślał konieczność uwzględniania praktycznego i empirycznego waloru przyjmowanych rozwiązań ${ }^{35}$. Dlatego ustanowienie mechanizmu zaawansowanej współpracy wymagało spełnienia dwóch przesłanek. Pierwszą było zaistnienie stanu faktycznego, w którym implementowanie postulowanej formy współpracy byłoby możliwe. Był to warunek wstępny powodzenia całego przedsięwzięcia. Drugą przesłanką było określenie kształtu instytucjonalnego i podstawowych zasad organizacyjnych.

2. Zdaniem Schumana zasadnicza przeszkoda dla tak projektowanej współpracy miała naturę psychologiczną ${ }^{36}$. Stwierdził, że łatwiej było przyznać i uznać niepodległość silnego i rozwiniętego regionu, niźli skłonić państwa do niewielkiego choćby ograniczenia swej suwerenności. Ze względu na historyczne doświadczenia i wysiłki, jakimi okupiono uzyskanie statusu niezależnego bytu państwowego, narody miały uczucie, że negują w ten sposób swą chwalebną przeszłość ${ }^{37}$. Materialną przesłankę dla zainicjowania współpracy w oparciu o ograniczenie suwerenności stanowiła kategoria określana mianem solidarité du fait, czyli solidarności „faktu” lub „czynu”. Bez wątpienia Schumanowska idea solidarności w stosunkach międzynarodowych nawiązywała do istniejącego wysokiego stopnia współzależności występującej między państwami ${ }^{38}$. Wychodziła jednak poza czyste stwierdzenie obiektywnego uwarunkowania faktycznego i nabierała charakteru imperatywu skłaniającego do działan ${ }^{39}$. „Solidarność jest naszym sumieniem, które sprzeciwia się niesprawiedliwości" " Podejście Schumana polegało na przewartościowaniu poglądu na stosunki wewnątrzeuropejskie. Reprezentując światopogląd neotomistyczny bliski humanizmowi integralnemu J. Maritaine'a ${ }^{41}$, opierał się Schuman na zasadzie równości, wyrażającej się w uznaniu powszechnego porządku prawnonaturalnego i imperatywie pozytywnej, przyjacielskiej postawy wobec bliźnich. W efekcie powolnego i stopniowego wzajemnego zbliżania zanikać miał podział na „my” i „oni”. Tym samym Schuman starał się wzmacniać więź łączącą mieszkańców całego kontynentu, podkreślając jedność cywilizacyjną, zwłaszcza zaś moralno-religijną. Było to równoznaczne z eliminacją politycznego nacjonalizmu, ekonomicznego protekcjonizmu i kulturowego izolacjonizmu poprzez rozwój zaufania w duchu

${ }^{35}$ R. Schuman, Comment ..., s. 7-8.

${ }^{36}$ Idem, Dla Europy..., s. 57.

${ }^{37}$ Idem, Organization of the Eurpean Defense Community (10 XII 1951), „VSD” t. XVIII, 1955, nr 7, s. 197; idem, European Integration ..., s. 616.

${ }^{38}$ R. Schuman, Comment..., s. 16.

${ }^{39}$ Idem, European Integration ..., s. 616.

${ }^{40}$ Idem, Est-il trop tard..., s. 230.

${ }^{41}$ J. Maritain, Humanizm integralny, Krąg, Warszawa 1981; idem, Człowiek i państwo, Znak, Kraków, 1993; R. Mougel, op. cit., s. 74-89. 
chrześcijańskiego, pokornego braterstwa ${ }^{42}$. „Liczy się przede wszystkim miłość do współbraci”"43. Na chrześcijańskim fundamencie zwalczania ludzkiego egoizmu pragnął zwalczać egoizm między narodami ${ }^{44}$. Tłumaczy to krytykę absolutyzacji granic i absolutnej suwerenności oraz podkreślanie wagi solidarności, która stała się aksjologicznym fundamentem całej koncepcji ${ }^{45}$. Solidarność, czyli „duch europejski”, stanowiła warunek dla współpracy opartej na ograniczeniu suwerenności ${ }^{46}$, gdyż stopniowo zastępować miała fikcję niepodległości ${ }^{47}$.

Idea solidarności łączyła się z ideą dobra wspólnego: pokoju, bezpieczeństwa i dobrobytu ${ }^{48}$ oraz odpowiadającej mu szerszej od narodowej wspólnoty. „Państwo musi uznać nadrzędność interesu zbiorowego, któremu winno podporządkować własny interes, spleciony zresztą z ogólnym"49. Tym thumaczyć należy tezy o konieczności wyjścia poza „nazbyt wąskie narodowe koncepcje" ${ }^{50}$. Służba wspólnocie szerszej niż narodowa stanowiła obowiązek równy tym, jakie wynikają z wierności narodowi ${ }^{51}$. Realizacji dobra wspólnego służyć miała proponowana współpraca. Reprezentowało ono wartość na tyle dużą, że jego realizacja uzasadniała ograniczenie suwerenności. Z drugiej strony partykularny interes narodowy pozostawał w ścisłej łączności ze wspólnym, co przekreślało możliwość uszczerbku dla pierwszego podczas realizacji drugiego. Powstająca większa wspólnota Europejczyków reprezentowałaby ,jedność w wielości”. Idea jedności nie była zatem sprzeczna z ideałem patriotycznym czy pojęciem ojczyzny. Jedność stała natomiast w sprzeczności z fanatyzmem, czyli zwyrodniałym nacjonalizmem, w który patriotyzm przekształca się w czasach zagrożenia ${ }^{52}$.

3. Postawa Schumana wobec idei ponadnarodowej nie była jednoznaczna. Dostrzegamy tu zależność od aspektu, w którym miała następować jej realizacja. Jednoznacznie pozytywne wypowiedzi na temat „unii ponadnarodowej” możemy znaleźć już w 1949 r. ${ }^{53}$ Ale jednocześnie Schuman zachowywał daleko posunięty sceptycyzm wobec idei ,ponadnarodowego organu”. Nie

${ }^{42}$ R. Schuman, Dla Europy..., s. 17, 27-29.

${ }^{43}$ Idem, List H. Hartmanna..., s. 13.

${ }^{44}$ P. Pflimlin, Polityka wyciagniętej dłoni, [w:] Robert Schuman: Chrześcijański..., s. 32.

${ }^{45}$ M. Gierycz, Znaczenie solidarności w polityce europejskiej Roberta Schumana, „Znaki Nowych Czasów” 2004, nr 12-13, s. 115-117; A. Muñoz, op. cit., s. 44-48.

${ }^{46}$ J. Wahl, op. cit., s. $38-40$.

${ }^{47}$ J. Lecanuet, op. cit., s. 113-14.

${ }^{48}$ R. Schuman, Dla Europy..., s. 22. Szerzej o dobru wspólnym w koncepcji Schumana: A.P. Fimister, Robert Schuman: Neo Scholastic Humanism and the Reunification of Europe, P. Lang, Brussels 2008, s. 198-201.

${ }^{49}$ R. Schuman, Przemówienie w Moguncji (21 III 1953).

${ }^{50}$ Idem, Comment les Françaises..., s. 2.

${ }^{51}$ Idem, Dla Europy..., s. 85.

${ }^{52}$ Ibidem, s. 20, 25-26, 69.

${ }^{53}$ Idem, Deklaracja przy podpisaniu Traktatu powolującego Radę Europy (5 V 1949), s. 2. 
wydaje się, by przekonał się do niej nawet w związku z propozycją Monne$\mathrm{ta}^{54}$. Można raczej przyjąć, że z tej przyczyny słowo ,ponadnarodowy” nie pojawia się w Deklaracja 9 maja, gdzie czytamy o l'autorité indépendante. W wywiadzie dla „Le Monde” udzielonym po przedstawieniu Deklaracji Schuman stwierdził wprost, że ,przedwcześnie jest mówić o ponadnarodowym organie" 55 . Ostatecznie przekonał się do idei organu ponadnarodowego w toku negocjacji nad traktatem Europejskiej Wspólnoty Węgla i Stali (czerwiec 1950-kwiecień 1951), uznając ją za indispensable ${ }^{56}$. Posługiwał się terminem coopération supranationale na opis całego planowanego przedsięwzięcia, broniąc przy tym nadal niezależności Wysokiej Władzy ${ }^{57}$.

Mimo akceptacji obu aspektów zasady Schuman nadawał jej różną treść. Latem 1950 r. opisał ponadnarodowość jako podległość czynnikowi zwierzchniemu w warunkach równości, przez który to czynnik rozumiał institution supranationale indépendante ${ }^{58}$. Było to ujęcie bliskie poglądom Monneta. Po koniec 1951 r. zapewnił, że „ponadnarodowy” nie był synonimem „federalnego" ${ }^{\text {. W }} 1954$ r. stwierdził, iż ponadnarodowość ,zakłada podporządkowanie się odgórnej organizacji, [podporządkowanie się] władzy wykonywanej wspólnie", przez co rozumiał stosowanie zasady większościowej i brak prawa weta $^{60}$. Dziesięć lat po ogłoszeniu Deklaracji dał wprost wyraz swej zachowawczej postawie, którą, jak sam twierdził, żywił od samego początku:

„Nadmiar zapału na rzecz ponadnarodowości czy zbyt ortodoksyjne rozumowanie doprowadzić może do niepowodzenia. [...] Termin władza ponadnarodowa budzi podejrzliwość. Tymczasem nie jest niczym innym jak przeniesieniem na obszar stosunków międzynarodowych zasady większościowej, która na płaszczyźnie narodowej uznawana jest za podstawowy sposób realizowania wolności”61.

${ }^{54}$ Kopia Planu z odręcznymi poprawkami Schumana, [w:] L'Europe de Robert Schuman, red. G. Eldin, P. Fournié, A. Moinet-Le Menn, Sorbonne, Paris 2001, s. XI-XIV.

55 „Le Monde”, 15 V 1950.

${ }^{56}$ Idem, Przemówienie inaugurujące konferencję poświęcona negocjacjom nad EWWS (20 VI 1950), s. 2. Wydaje się, iż na ewolucję poglądu Schumana wpływ miała niechętna i nieprzejednana postawa rządu Zjednoczonego Królestwa. L'Europe de Robert Schuman..., s. 57.

57 R. Schuman, Depesza do francuskiego ambasadora w Londynie R. Massigili'ego (5 VII 1950), [w:] G. Bossuat, Faire l'Europe sans defaire la France. 60 ans de politique d'unite europeenne des gouvernements et des presidents de la Republique francaise (1943-2003), P. Lang, Bruxelles 2005, s. 305-306. Wysoka Władza (la Haute Autorié) stanowiła w świetle założeń Planu Schumana centralną instytucję, a wręcz rdzeń przyszłej organizacji. Znalazło to potwierdzenie w treści postanowień Traktatu o EWWS. Szerzej o tym problemie: A. Madeja, Europejska Wspólnota Wegla i Stali a suwerenność państwa członkowskiego. Aspekt instytucjonalno-doktrynalny, „Zeszyty Naukowe Uniwersytetu Kardynała Stefana Wyszyńskiego” t. XI, 2011, nr 4, s. 319-348.

58 R. Schuman, Przemówienie przed Zgromadzeniem Rady Europy (10 VIII 1950), s. 2; idem, European Integration..., s. 616.

${ }^{59}$ Idem, Organization of the Eurpean Defense..., s. 197-198.

${ }^{60}$ Idem, European Integration..., s. 616.

${ }^{61}$ Idem, Wystapienie $w$ dziesiąta rocznicę ogłoszenia Planu Schumana, „Paris-Presse”, 17 V 1960. 
Istota ponadnarodowości wyrażała się więc $\mathrm{w}$,prawie większości, dobrowolnie przyjętym w okolicznościach i na warunkach uprzednio określonych"62.

Analiza przywołanych wypowiedzi pozwala dostrzec wyraźne przesunięcie akcentu: podległość niezależnej instytucji zastąpiona zostaje podległością wspólnemu mechanizmowi decyzyjnemu (zasadzie większościowej), a w praktyce podległością wspólnej decyzji podjętej przez państwa w trybie tejże zasady. W ten sposób Schuman powrócił niejako do wczesnych założeń, zawężając stosowanie zasady ponadnarodowści do płaszczyzny stosunków między państwami (,ponadnarodowa kooperacja”) i czyniąc zeń w pierwszym rzędzie kwalifikację wspólnoty, a jedynie wtórnie cechę jej instytucji. Jeśli powiązać powyższe z założeniem, że podejmowanie decyzji w oparciu o zasadę większościową był rdzeniem procedury demokratycznej ${ }^{63}$, to istotą ponadnarodowości stawał się ideał demokratyczny podniesiony do poziomu stosunków międzypaństwowych ${ }^{64}$. Tłumaczy to słowa, że jednomyślność między narodami nie była częstsza niż między jednostkami ${ }^{65}$. Stąd troska o wartości demokracji wymagała porzucenia zasady jednomyślności. Jeżeli natomiast uznać jednomyślność za wykładnik pełnej suwerenności, to wniosek o konieczność ograniczenia tej ostatniej nasuwał się sam. „Państwa ograniczają swą suwerenność i z góry akceptują decyzje podejmowane we wspólnocie większością głosów"66. Przypomnijmy w tym miejscu, że dla Schumana jednym z czynników zagrażających demokracji była właśnie pełna suwerennośćc7. W takim ujęciu ograniczenie suwerenności nie było celem samym w sobie, ale jedynym środkiem realizacji wartości wyższych ${ }^{68}$.

Ponadnarodowość była więc nową, rewolucyjną, ale pokojową w realizacji metodą integracji ${ }^{69}$. Jej urzeczywistnienie wymagało, by narody nie tkwiły w izolacji, ale współdziałały solidarnie wiedzione jednym duchem ${ }^{70}$, gdyż musiały wykazywać „niezwyczajną gotowość do zaakceptowania cudzej woli, która wynika z konieczności podporządkowania się decyzjom większości"71. W ten sposób ponadnarodowość stawała się czynnikiem intensyfikacji i przekształcania solidarności ${ }^{72}$, co wyrażało zaistnienie tzw. „,solidarności

${ }^{62}$ Idem, Dla Europy..., s. 18, 29.

${ }^{63}$ R. Schuman, Dla Europy..., s. 43; idem, Deklaracja przy podpisaniu Traktatu powolujacego Radę Europy (5 V 1949), s. 3

${ }^{64}$ Idem, Dla Europy..., s. 29.

${ }^{65}$ Idem, Musimy zbudować Europę, „Rheinischen Merkur”, 1 I 1953.

${ }^{66}$ F. Roth, op. cit., s. 536-537.

${ }^{67}$ R. Mougel, op. cit., s. 90-91.

${ }^{68}$ R. Schuman, Przemówienie przed Zgromadzeniem Rady Europy (10 VIII 1950), s. 2.

${ }^{69}$ Idem, European Integration ..., s. 616.

${ }^{70}$ A. Muñoz, op. cit., s. 51.

${ }^{71}$ R. Schuman, Tysięczna rocznica zwycięstwa na Lechowym Polu (VI 1955), [w:] J. Wahl, op. cit., s. 75-76.

${ }^{72}$ B. Clappier, Decydujace lata, [w:] Robert Schuman: Chrześcijański..., s. 51-53. 
ponadnarodowej"73. Jednocześnie Schuman stwierdzał, że aplikacja zasady większościowej wymagała rozwagi ${ }^{74}$. Zdecydowane przejście na pozycje zasady większości głosów oznaczało dla niego zbyt duże ryzyko. „Wydawałoby się to niemożliwe, a przynajmniej przedwczesne, by stosować tę metodę do wszystkich przypadków"75. Stąd nierzadko opowiadał się za konsultacjami i jednomyślnością, czyli klasyczną współpracą międzyrządową ${ }^{76}$.

Jak widać, ponadnarodowość nigdy nie miała doprowadzić do wyłonienia „rządu” czy „,narodu”. Dlatego ostatecznie uznamy, iż była wypadkową suwerenności, solidarności oraz imperatywu współpracy ${ }^{77}$. Tylko w takim stanie rzeczy należy zgodzić się z opinią Michela Debré o Schumanie jako o „żarliwym obrońcy ponadnarodowości" 78 .

4. Usunąwszy przeszkody natury psychologicznej i wytworzywszy wolę współdziałania, należało zorganizować współpracę. Opracowanie jej kształtu było bardzo trudnym zadaniem ze względu na brak historycznych odpowiedników $^{79}$. Można przyjąć, że idea solidarności i dobra wspólnego determinowała nie tylko moment zainicjowania współpracy, ale także jej kształt. Od strony organizacyjnej nie miała ona przyjąć formy zwykłej organizacji międzynarodowej, paktu czy sojuszu, ale tzw. „wspólnoty”, stanowiącej instytucjonalne odzwierciedlenie solidarité du fait i wspólnych interesów ${ }^{80}$.

Solidarność była zrębem całej konstrukcji i podstawą, na której miała ona operować. Wspólnota oznaczała eliminację egoizmu na rzecz realizacji wspólnego interesu, trwałe zapewnienie jedności, wolności, równości oraz partnerstwo i dobrowolną współpracę ${ }^{81}$. Jak widać wspólnota posiadała własne cele $\mathrm{i}$ interesy, pozostające $\mathrm{w}$ związku z narodowymi, ale nie będące prostą sumą tych ostatnich ${ }^{82}$. Z drugiej strony cel wspólnoty nie polegał na realizacji pewnego doraźnego interesu, ale dobra ogólnego, które stawało się punktem odniesienia dla dalszych celów politycznych ${ }^{83}$. Dlatego wspólnota to twór „nierozwiązywalny i nieograniczony czasowo, z którym wiąże się teraźniejszość i przyszłość" 84 .

${ }^{73}$ R. Schuman, Przemówienie przed Zgromadzeniem Rady Europy (10 VIII 1950), s. 4.

${ }^{74}$ L'Europe de Robert Schuman..., s. 70.

${ }^{75}$ F. Roth, op. cit., s. 536-537.

${ }^{76}$ L'Europe de Robert Schuman..., s. 71.

${ }^{77}$ R. Schuman, Deklaracja przy podpisaniu Traktatu powolującego Radę Europy (5 V 1949), s. 2-3.

${ }^{78}$ F. Roth, op. cit., s. 509.

${ }^{79}$ R. Schuman, France and Europe..., s. 359.

${ }^{80}$ E.B. Haas, The Uniting of Europe. Political, Social and Economic Forces 1950-1957, Stanford Universty Press, Stanford 1958, s. 244.

${ }^{81}$ R. Schuman, Dla Europy..., s. 18.

${ }^{82}$ Idem, Comment..., s. 6.

${ }^{83}$ M. Gierycz, op. cit., s. 115-117.

${ }^{84}$ R. Schuman, Dla Europy..., s. 67. 
Taka bliska i intensywna więź wymagała szczególnego zaangażowania ze strony państw: wniesienia cząstki dorobku i tradycji oraz potencjału każdego $\mathrm{z}$ nich ${ }^{85}$. Schuman zakładał więc, że materialną podstawą wspólnoty miało się stać połączenie zasobów i wspólnych interesów ${ }^{86}$. Drugim argumentem przemawiającym za dokonaniem wymiernego wkładu był fakt, że skuteczna współpraca wymagała czegoś więcej niż tylko dobrej woli państw deklarujących samoograniczenie swej suwerenności. U podstaw współpracy znaleźć się musiał solidny fundament, uniemożliwiający państwom uchylanie się od wykonania zobowiązań przyjętych przez każde $\mathrm{z}$ nich ${ }^{87}$. Wreszcie, pomiędzy pojawieniem się solidarności a zintensyfikowaną współpracą zachodziło sprzężenie zwrotne. $Z$ jednej strony solidarność warunkowała współpracę, $z$ drugiej natomiast czynnikiem aktywizującym „ducha europejskiego" miały być instytucje ${ }^{88}$ : „demony narodów” mogły zostać pokonane przez siłę ducha, pod warunkiem, że był on ucieleśniony w instytucjach ${ }^{89}$. Było to równoznaczne z koniecznością powołania gwaranta ,dyscypliny ponadnarodowej" '90. Postulowane szczególne instytucje działały na rzecz wspólnoty: jej celów i jej interesów, dlatego w ich skład nie mieli wchodzić przedstawiciele państw. Podobnie, nie miały służyć jedynie uzgadnianiu narodowych punktów widzenia. Nie były zwykłymi wykonawcami delegowanej na nie władzy państwowej, ale posiadały własne, autonomiczne uprawnienia ${ }^{91}$. Ich źródłem była delegacja części suwerenności (,władz suwerennych”) dokonana wspólnie przez państwa ${ }^{92}$, un certain abandon de la souveraineté au profit de la Autorité commune ${ }^{93}$. „Państwa winny ustąpić i wyrzec się części swej autonomii na rzecz wspólnego organu" ${ }^{94}$. Transfer ten stanowił realizację wspom-

${ }^{85}$ Ibidem, s. 57.

${ }^{86}$ Ibidem, s. 19, 31; idem, Przemówienie przed Zgromadzeniem RE (10 VIII 1950), s. 4; idem, Wystapienie na forum konferencji przygotowawczej poświęconej wspólnocie zdrowia (12 XII 1952), s. 2; idem, Comment les Françaises..., s. 15; idem, Wystapienie przed Zgromadzeniem Narodowym (25 VII 1950), s. 3.

${ }^{87}$ Ibidem, s. 28; idem, Comment..., s. 6.

${ }^{88}$ J. Wahl, op. cit., s. 38-40.

${ }^{89}$ P. Pflimlin, op. cit., s. 32.

${ }^{90}$ R. Schuman, Comment..., s. 16; por. idem, Dla Europy..., s. 29, 64; idem, Przemówienie przed Zgromadzeniem Rady Europy (10 VIII 1950), s. 2, 4.

${ }^{91}$ Idem, Comment ..., s. 6-7.

${ }^{92}$ Idem, Przemówienie inaugurujące konferencję poświęcona negocjacjom nad EWWS (20 VI 1950), s. 2. Błąd w polskim przekładzie (R. Schuman, Dla Europy..., s. 57) polega na przetłumaczeniu pouvoirs souverains (R. Schuman, Pour l'Europe, Nagel, Genève 2007, s. 89) jako „suwerenna władza". Poprawnie tłumaczenie winno mieć formę mnogą ,władze suwerenne” i oznaczać elementy składowe suwerenności. Z kolei autorité commune dość ezopowo przełożono jako „wspólne władanie”. Wydaje się, że terminem odpowiadającym francuskiemu oryginałowi byłaby „wspólna instytucja” albo „wspólny organ”.

${ }^{93}$ R. Schuman, Przemówienie przed Zgromadzeniem RE (10 VIII 1950), s. 2.

9424 XI 1950 r. Cyt. za: E. Bonnefous, L'Europe à face de son destine, Sirey, Paris 1953, s. 183-184; R. Schuman, European Integration..., s. 616. 
nianego poważnego zaangażowania państw i wnoszonego przez nie wkładu (zasobów), czyli w istocie przesądzał o ich partycypacji we wspólnocie. Był więc podstawowym, organizacyjno-instytucjonalnym warunkiem jej powołania, nie podlegał dyskusji i musiał zostać a priori zaakceptowany ${ }^{95}$.

Zauważmy, że Schuman nie posługiwał się kategorią „,kompetencji wspólnoty", gdyż zawsze ujmował zakres jej władzy z perspektywy uprawnień jej organów. Gdyby jednak zastosować ją do jego poglądów, to okazałoby się, iż nie była ona kategorią jednorodną. Składały się nią uprawnienia instytucji niezależnej od rządów oraz te, które w ramach wspólnoty wykonywane były przez organ międzyrządowy. Zróżnicowanie dotyczyłoby także źródła. Jakkolwiek oba aspekty wiązały się z ograniczeniem suwerenności, to w pierwszym przypadku byłby to transfer części suwerenności na organ ponadnarodowy, w drugim zaś uznanie stosowania zasady większościowej w odniesieniu do pewnej kategorii spraw. Ze względu na skupienie uwagi na niezależnym organie Schuman zdawał się niemal całkowite pomijać tę drugą części kompetencji, utożsamiając uprawnienia organu ponadnarodowego z kompetencją całej organizacji. Tymczasem, stosownie do opisanej wyżej ewolucji znaczenia zasady ponadnarodowej, ów drugi aspekt kompetencji zyskiwał z czasem na znaczeniu w opinii samego Schumana.

Charakterystyczne dla Monneta tezy mówiące o ,suwerenności wspólnoty"96 spotkamy u Schumana tylko w kontekście Europejskiej Wspólnoty Politycznej (1952-1954) ${ }^{97}$. Poza okresem walki o EWP był on zdania, że wspólnota wykonuje sumę fragmentów suwerenności (praw suwerennych) każdego $\mathrm{z}$ państw ${ }^{98}$. Mówił o une fusion ou mise en commun du pouvoirs actullement exercés [...] par les gouvernements ${ }^{99}$. Zdając Zgromadzeniu Narodowemu relację z postępów negocjacji nad Traktatem o EWWS, określił instytucję ponadnarodową mianem „wspólnego organu państw, wyrażającego istniejącą między nimi solidarność, za sprawą którego dokonują one częściowej fuzji

95 Idem, Origines ..., s. 14.

96 J. Monnet, Les Etats-Unis d'Europe ont commencé, Laffont, Paris 1955, s. 60; idem, Mémoires, Fayard, Paris 1976, s. 401. Szerzej o modelu współpracy autorstwa J. Monneta: A. Madeja, Krytyka klasycznego pojęcia suwerenności w doktryny integracyjnej Jeana Monneta (lata 19141949), [w:] Moralność i władza jako kategorie myśli politycznej, red. J. Justyński, A. Madeja, Wolters Kluwer, Warszawa 2011, s. 391-434; idem, Koncepcja integracji wspólnotowej Jeana Monneta (lata 1950-1955), „Roczniki Humanistyczne KUL” [w druku].

97 J. Wahl, op. cit., s. 63-64. Szerzej o EWP: A.H. Robertson, The European Political Community, „British Yearbook of International Law” 1952, s. 383-401; B. Karp, The Draft Constitution for a European Political Community, „International Organization” t. VIII, 1954, nr 2, s. 181-202; H.W. Briggs, The Proposed EPC, „American Journal of International Law” t. XLVII, 1954, nr 1, s. 110-122; R. Cardozo, The Project for a Political Community, 1952-54, [w:] The Dynamics of European Union, red. R. Pryce, Croom Helm, London 1987, s. 49-77; R.T. Griffiths, Europe's First Constitution. The European Political Community, 1952-1954, Federal Trust, London 2000.

${ }^{98}$ E.B. Haas, op. cit., s. 244.

${ }^{99}$ R. Schuman, Przemówienie przed Zgromadzeniem RE (10 VIII 1950), s. 2. 
swych suwerenności" ${ }^{100}$. Pozwala to postawić tezę, że pogląd Schumana najbliższy był idei „suwerenności zbiorowej”, wykonywanej w ramach wspólnoty przez organ ponadnarodowy ${ }^{101}$. Jednocześnie dodawał on, że „kompetencja instytucji ponadnarodowych obejmuje raczej kwestie techniczne niźli funkcje, jakie składają się na suwerenność państwa" ${ }^{102}$. Takie określenie charakteru władzy wykonywanej przez wspólnotę thumaczy, dlaczego była to „władza suwerenna” (souveraine, tj. niezależna), nie zaś „suwerenność”. Ale nadal było to kwantum władzy autonomicznie posiadanej przez instytucję, nie zaś prosta i odwracalna delegacja władzy państwowej. Od strony formalnej kompetencje przekazywane były z zachowaniem procedur konstytucyjnych i ściśle określone traktatem ${ }^{103}$. Od strony materialnej natomiast miały być adekwatne do zakresu dobra wspólnego, czyli wspólnoty interesów i proporcjonalne do nałożonych nań zadań. Schuman jawił się przy tym jako zdecydowany zwolennik zasady subsydiarności. „Wspólnota powinna [...] przejmować pozytywne zadania, o ile mogą być one przez wspólnotę lepiej wykonywane lub też jeżeli mogą być rozwiązane wyłącznie na drodze wspólnego, planowego wysiłku wielu członków"104.

Podsumowując uznamy, że istotą wspólnoty stawała się synteza idei i materii: solidarności, dobra wspólnego, konkretnych interesów, zasobów i władzy. Ich suma znajdowała wyraz w niezależnych instytucjach, których powołanie urastało w oczach Schumana do istoty wspólnoty, oraz w większościowym trybie podejmowania decyzji. Powołana mocą decyzji parlamentów narodowych wspólnota zaczynała żyć własnym życiem, chroniona przed niepewnością i kaprysami polityki poszczególnych państw ${ }^{105}$. W efekcie wspólnota nabierała nie między-, ale ponadnarodowego charakteru, gdyż opierała się na narodach jako fundamencie, ciesząc się niezależnymi kompetencjami uzyskanymi na skutek ograniczenia suwerenności państw. Oznaczało to więc trwałą modyfikację suwerenności i przesądzało o wyjątkowości całego projektu ${ }^{106}$.

5. Potencjalnie dopuszczał Schuman współpracę w bardzo szerokim zakresie, obejmującym materie ekonomiczne, wojskowe, polityczne, a nawet

${ }^{100}$ Idem, Wystapienie przed Zgromadzeniem Narodowym (25 VII 1950), s. 3.

${ }^{101}$ A. Marszałek, Suwerenność a integracja europejska w perspektywie historycznej, Instytut Europejski, Łódź 2000, s. 304-307.

102 R. Schuman, French Foreign Policy..., s. 329. Zgodnie z brytyjskim przekazem z 15 IX 1952 r. Schuman w reakcji na Plan Edena oświadczył, iż Francja nie postrzegała EWWS jako rdzenia (hub) integracji, ale instytucję o ograniczonych funkcjach. Documents on British Policy Overseas, red. R. Bullen, M.E. Pelly, HMSO, London 1986, t. II, cz. 1, s. 962. Jednoznacznie stwierdził, że EWWS nie wykonywała władzy politycznej. R. Schuman, Przemówienie przed Zgromadzeniem Rady Europy (10 VIII 1950), s. 3.

${ }^{103}$ Idem, Wystapienie przed Zgromadzeniem Narodowym (25 VII 1950), s. 5; idem, Przemówienie przed Zgromadzeniem RE (10 VIII 1950), s. 2-3; idem, Origines ..., s. 13.

${ }^{104}$ Idem, Przemówienie w Moguncji (21 III 1953).

${ }^{105}$ Idem, Dla Europy..., s. 67-68.

106 „Neue Züricher Zeitung”, 1 VI 1953. 
duchowe (spirituel) ${ }^{107}$. Przechodząc do konkretnych propozycji, jednoznacznie opowiadał się za ścisłym określeniem zakresu współpracy ${ }^{108}$. Definiując zasadę ponadnarodowości, określił ją jako „ograniczoną do podstawowych problemów z zakresu wspólnych interesów"109. Jeśli powyższe powiązać z leżącym u podstaw wspólnoty złączeniem zasobów ${ }^{110}$, to implicite oznaczało to ideę integracji sektorowej. $\mathrm{Z}$ drugiej strony za sprawą kategorii solidarité du fait, konkretnych interesów i zasobów współpraca musiała mieć komponent ekonomiczny. Stąd punktem wyjściowym była sektorowa integracja gospodarcza, której EWWS była pierwszym przykładem realizacji ${ }^{111}$. Schuman wierzył jednocześnie $\mathrm{w}$ działanie funkcjonalistycznego mechanizmu spill-over: „Wyłom został zrobiony i będzie się nieustannie powiększał”112. Chociaż oparta na materiach gospodarczych, wspólnota wybiegała swymi celami w sferę dalszych celów pozaekonomicznych ${ }^{113}$. Od marca 1951 r. podkreślał, że formy integracji ekonomicznej wymagają instytucji politycznych, gdyż poszczególnie inicjatywy mogą być rozbieżne, jeśli zabraknie scalającej instancji politycznej ${ }^{114}$. W tym przekonaniu utwierdził go Projekt Wspólnoty Obronnej ${ }^{115}$, gdyż dotykała ona fundamentalnych kwestii wojny i pokoju, doniosłych z punktu widzenia życia obywateli i losu narodów. Armia europejska nie miała stanowić wspólnej „Legii Cudzoziemskiej”. Planowana wspólnota przejęłaby więc kompetencje państw w zakresie rekrutacji, szkolenia i utrzymania sił zbrojnych. Dlatego Schuman opowiadał się za docelowym całkowitym usunięciem armii narodowych ${ }^{116}$. Formą integracji politycznej była wspomniana wyżej Wspólnota Polityczna. Klęska projektu EWO/EWP uzmysłowiła mu jednak, iż Europa nie dojrzała jeszcze do integracji polityki zagranicznej i obrony, czyli kolektywnego podejmowania decyzji dotyczących wojny i pokoju, a więc odnoszących się do podstaw suwerenności ${ }^{117}$. Dostrzegał szansę w dalszym powoływaniu instytucji wyspecjalizowanych, służących realizacji wspólnych potrzeb humanitarnych, czego przykładem była inicjatywa wspólnoty zdrowia (communauté de santé) $)^{118}$.

${ }^{107}$ Rozważania Schumana ze stycznia 1949, [w:] L'Europe de Robert Schuman..., s. I-V.

${ }^{108}$ R. Schuman, Przemówienie przed Zgromadzeniem RE (10 VIII 1950), s. 5.

${ }^{109}$ Idem, Dla Europy..., s. 18, 29.

${ }^{110}$ Ibidem, s. 19, 31.

${ }^{111}$ R. Schuman, Origines ..., s. 21.

112 Idem, Dla Europy... s. 83.

${ }^{113}$ Idem, France and Europe..., s. 349-350.

${ }^{114}$ Idem, Dla Europy..., s. 63, 70; idem, France and Europe..., s. 358.

115 Szeroko o projekcie EWO: E. Fursdon, European Defence Community. A History, Macmillan, New York 1980; A. Clesse, Le projet de la CED du Plan Pleven au „crime” du 30 août: historie d'un malentendu européen, Nomos, Baden-Baden 1989.

${ }^{116}$ R. Schuman, Otwarcie konferencji poświęconej negocjacjom nad EWO (15 II 1951), s. 2-3.

${ }^{117}$ Idem, Dla Europy..., s. 71-72.

118 Idem, Wystapienie na forum konferencji przygotowawczej poświęconej Wspólnocie Zdrowia (12 XII 1952), s. 2. 
6. Schuman nie przedstawił nigdy szczegółowej analizy struktury wspólnoty. Wyraził jedynie pogląd, iż była ona inspirowana ,poniekąd reżimem konstytucyjnym" 119 . Dotychczasowe rozważania pozwalają jednak wyprowadzić dwa wnioski istotne dla tego zagadnienia. Po pierwsze, istotą wspólnoty był niezależny od państw organ ponadnarodowy. Warunek powyższy nie oznaczał bynajmniej braku innych organów. Z kolei treść, jaką nadał on idei ponadnarodowości pozwala uznać kluczowe znaczenie zasady większościowej, która doznawała jednak pewnych ograniczeń ze względu na charakter i wagę rozstrzyganych materii.

Treść instrukcji wydanych na potrzeby negocjacji nad EWWS oraz jego osobisty w nich udział pozwalają uznać, że Schuman opowiadał się za silnym organem ponadnarodowym, który stanowił rdzeń Wspólnoty ${ }^{120}$. Wysoka Władza winna wykonywać swoje kompetencje stosownie do własnej oceny (appréciation) sytuacji, a jej decyzje wiązały (lieront) państwa i były wykonywane (exécutoires) na ich terytorium. Organ ponadnarodowy nie posiadał (i nie miał posiadać) uprawnień o charakterze prawodawczym i legislacyjnym, a jedynie wykonawczym i administracyjno-zarądczym ${ }^{121}$. Uznamy więc, że jego autonomiczna władza nie miała politycznego waloru. Organ ponadnarodowy miał być w pełni niezależny od państw ${ }^{122}$. Kwestia ta urastała do rangi raison d'être projektu. Jednak niezależność Władzy nie mogła być absolutna i nie mogła oznaczać jej nieodpowiedzialności. Przede wszystkim wymagało to ścisłego określenia właściwości rzeczowej Władzy ${ }^{123}$. Dostrzegamy tu związki z koncepcją integracji sektorowej. W aspekcie instytucjonalnym oznaczało to powołanie Zgromadzenia i Sądu, zapewniających odpowiednio demokratyczną kontrolę i legitymację oraz poszanowanie zasady praworządności ${ }^{124}$. Dodajmy, iż Zgromadzenie miało posiadać uprawnienie nie tylko do odwołania członków Władzy, ale także do powołania jej nowego kolegium ${ }^{125}$. Jednocześnie Schuman nie oponował wobec powołania organu międzyrządowego, czyli Rady. Kładł nacisk na ścisłą współpracę Władzy i Rady oraz sugerował powołanie międzyrządowego komitetu koordynacyjnego. Stanowiło to kon-

119 Idem, Comment ..., s. 17.

${ }^{120}$ D. Spierenburg, R. Poidevin, Historie de la Haute Autorité de la Communauté européenne du charbon et de l'acier. Expérience supranationale, Bruylant, Bruxelles 1993, s. 15; R. Poidevin, Le rôle personnel de Robert Schuman dans les négociations CECA, juin 1950-avril 1951, [w:] Die Anfänge des Schuman-Plans 1950/51, red. K. Schwabe, Bruylant, Bruxelles 1988, s. 105.

${ }^{121}$ R. Schuman, French Foreign Policy..., s. 329; idem, Przemówienie przed Zgromadzeniem Rady Europy (10 VIII 1950), s. 3.

${ }^{122}$ Idem, Wystapienie przed Zgromadzeniem Narodowym (25 VII 1950)..., s. 6; idem, Przemówienie przed Zromadzeniem Rady Europy (10 VIII 1950), s. 2.

${ }^{123}$ Idem, Przemówienie przed Zgromadzeniem RE (10 VIII 1950), s. 2-3.

124 Idem, Wystapienie przed Zgromadzeniem Narodowym (25 VII 1950)..., s. 5; idem, Przemówienie przed Zgromadzeniem RE (10 VIII 1950), s. 4-5; idem, Comment..., s. 17. Schuman przystał na przyjmowanie skarg i sugestii od wszystkich, którzy podlegali Władzy.

${ }^{125}$ R. Schuman, Przemówienie przed Zgromadzeniem RE (10 VIII 1950), s. 5. 
sekwencję modelu sektorowego i konieczność harmonizacji interesów wspólnych i partykularnych ${ }^{126}$.

Otwierając 15 II 1951 r. negocjacje nad EWO, Schuman postulował powołanie silnego i samodzielnego Komisarza Obrony ${ }^{127}$. Jednak już pod koniec tego roku zmienił zdanie. W przeciwieństwie do EWWS, Wspólnota Obronna potrzebowała instytucji politycznych ze względu na ciężar gatunkowy spraw poddanych integracji. Stąd kluczową rolę winna odgrywać Rada Ministrów, kontroli której podlegałby Komisarz ${ }^{128}$. Potwierdza to, iż według Schumana instytucji ponadnarodowej w typie Wysokiej Władzy wolno było powierzyć wykonywanie funkcji o charakterze niepolitycznym. Ale jednocześnie ministrowie nie byli predestynowani do pełnienia takiej funkcji. Armia europejska jako supranational i dénationalisée nie mogła stanowić narzędzia polityki narodowej ani zachowywać narodowej lojalności, więc jej podległość rządom narodowym była wykluczona ${ }^{129}$. Z drugiej strony względy efektywności wymagały, by decyzje podejmowane były przez Radę Ministrów EWO większością głosów. Takie rozwiązanie mogło doprowadzić do podniesienia zarzutu naruszenia konstytucji państw członkowskich, zastrzegających decyzje w zakresie wojny i pokoju dla parlamentów narodowych. Rozwiązaniem, jakie wypływało z powyższych rozważań było powołanie wspólnego parlamentu Wspólnoty pochodzącego docelowo z wyborów bezpośrednich, przed którym Rada ponosiłaby polityczną odpowiedzialność ${ }^{130}$. W ten sposób Wspólnota uzyskałaby co prawda wąskie, ale bez wątpienia wysoce polityczne kompetencje, wykonywane przez demokratyczny organ reprezentacyjny.

Po klęsce projektu EWO/EWP (30 VIII 1954) Schuman ograniczył swe postulaty do demokratyzacji Wspólnot na drodze przeprowadzenia bezpośrednich wyborów do Zgromadzenia. Jego kompetencje nie miały mieć jednak kluczowego znaczenia. Rola Zgromadzenia winna polegać na wspieraniu działań Wspólnot i zapewnieniu kontaktów z obywatelami ${ }^{131}$. W 1958 r. postulował integrację polityczną, która nie oznaczała przyznania ponadnarodowej instytucji uprawnień w zakresie wspólnej polityki zagranicznej. Winna to być koordynacja działań państw, opierająca się na zasadzie solidarności, dotycząca ustalania i realizacji zamierzeń ${ }^{132}$.

Spróbujmy uogólnić przedstawione założenia. Instytucja ponadnarodowa w typie Wysokiej Władzy wykonywała zasadniczą część kompetencji Wspólnoty. Jeśli jednak nowej organizacji przyznano władzę o politycznym walorze,

${ }^{126}$ Idem, Depesza do R. Massigliego (5 VII 1950)..., s. 305-306; idem, Przemówienie przed Zgromadzeniem RE (10 VIII 1950), s. 3.

${ }^{127}$ Idem, Otwarcie konferencji poświęconej negocjacjom nad EWO (15 II 1951), s. 3.

${ }^{128}$ Idem, Organization of the Eurpean Defense..., s. 198-199.

129 Ibidem, s. 198.

${ }^{130}$ Idem, France and Europe..., s. 358; idem, Organization of the Eurpean Defense..., s. 198.

${ }^{131}$ Idem, Dla Europy..., s. 63, 70

${ }^{132}$ Idem, Est-il trop tard..., s. 230. 
to jej wykonywanie powierzał Schuman bez wahania organowi międzyrządowemu. W takim wypadku zasada wspólnotowa realizować się miała w dwójnasób: w trybie większościowego podejmowania decyzji na forum Rady oraz poprzez kontrolę sprawowaną przez organ parlamentarny. Jak widać, wspólnota nie miała doprowadzić do wykształcenia się rządu ponadnarodowego. Jej mechanizm instytucjonalny określić można jako kolektywne podejmowanie decyzji, których wykonywanie przypadało niezależnej instytucji, oraz tryb niezależnej kontroli obu tych procesów.

7. Schuman posłużył się terminem „Stany Zjednoczone Europy”, opisując nową formę współpracy już w kwietniu 1942 r. ${ }^{133}$ Nie podał jednak żadnych szczegółów, poza wskazaniem demokratycznej podstawy oraz celu w postaci zapewnienia pokoju. Niemal równo sześć lat później podał pod rozwagę utworzenie federacji, na rzecz której państwa zrezygnowałyby w ograniczonym zakresie z części swej suwerenności ${ }^{134}$. Następnie wyraził nadzieję, że z Rady Europy wyłoni się „rozległa i trwała unia ponadnarodowa"135. Zdaniem większości autorów, Deklaracja 9 maja 1950 r. to exemple lumineux dla wszystkich adherentów integracji politycznej, zorientowanej na cel federalny ${ }^{136}$. Jak sam wyznał, nie miał wówczas precyzyjnej wizji rozwoju ${ }^{137}$. Dlatego fundamentem dynamicznej koncepcji federalistycznej stała się dlań EWWS ${ }^{138}$. Był przekonany, iż stopniowe powoływane kolejnych instytucji wyspecjalizowanych (autorités européennes spécialisées) będzie drogą do ustanowienia une autorité européenne unique [et] souveraine ${ }^{139}$ oraz une communauté généralisée $^{140}$. W dniu 24 XI 1950 r. Schuman wprost opowiedział się za konstytucją federalną i politycznym organem ponadnarodowym jako celem, zaś politykę federacyjną uznał za realny środek działania ${ }^{141}$. O specyfice tej federacji niech świadczy fakt, że jako jej podstawę prawną wskazał podpisaną trzy tygodnie wcześniej Europejską konwencję praw człowieka. Dodał, że Konwencja stać się miała „pomostem pomiędzy narodową i ponadnarodową suwerennością" ${ }^{142}$. Federacja miała objąć materie politycz-

133 J. Wahl, op. cit., s. 17-18, 20; G. Audisio, A. Chiara, Twórcy zjedniczonej Europy, PAX, Warszawa 2007, s. 35-36, 4; R. Lejeune, Une âme pour l'Europe, Fribourg, Saint-Paul 1986. s. 90; F. Roth, op. cit., s. 250; G. Bossuat, Les fondateurs de l'Europe unie, Belin, Paris 2001, s. 118.

134 J. Wahl, op. cit., s. 32-33.

135 R. Schuman, Deklaracja przy podpisaniu Traktatu powotujacego Radę Europy (5 V 1949), s. 2; R. Poidevin, Robert Schuman, homme d'Etat, 1886-1963, Imprimerie nationale, Paris 1986 , s. 231-234.

${ }^{136}$ C.G. Anta, op. cit., s. 68.

137 R. Schuman, Origines ..., s. 11.

138 W. Hallstein, Utworzenie Wspólnoty i jej założyciel, [w:] Robert Schuman: Chrześcijański..., s. 110-111.

${ }^{139}$ R. Schuman, Comment..., s. 6-7, 17.

${ }^{140}$ Idem, Origines..., s. 11.

141 Słowa Schumana przytacza: E. Bonnefous, op. cit., s. 183-184.

${ }^{142}$ J. Wahl, op. cit., s. 63-64. 
ne i obronność, czego instytucjonalizacją miały stać się odpowiednio EWP i EWO. W pełni odpowiadała mu treść art. 38 EWO, który stał się podstawą dla prac na projektem Wspólnoty politycznej. Projekt przewidywał powołanie konfederacji albo federacji opartej na dwuizbowym parlamencie i zasadzie podziału władz. Schuman podkreślał przy tym, że nie chciał powołania superpaństwa $^{143}$ i zapewniał, że EWP wykroczy poza konfederację, ale nie przybierze formy państwa związkowego ${ }^{144}$. Jej rolą miało być koordynowanie działań instytucji sektorowych ${ }^{145}$. Opisując ostateczny efekt integracji, stwierdził jednak, iż „Francja i Niemcy połączą się z możliwie wieloma krajami w jeden organizm" 146 . W maju 1960 r. stwierdził, że idea federacji zawarta jest $\mathrm{w}$ duchu Wspólnoty, ale sugerował jednocześnie, by nie przyjmować zbyt ambitnych konstrukcji prawnych ${ }^{147}$. W ostatecznym rozrachunku integracja winna uzyskać aspekt polityczny, co wyczerpywało się w nadaniu jej demokratycznej podstawy w postaci Zgromadzenia pochodzącego z bezpośrednich wyborów.

Wydaje się, że Schuman uznawał „federację europejską” za kategorię zbyt abstrakcyjną. Federację, czyli ,głęboką i bogatą w perspektywy formułę myśli prawnej”, utożsamiał z ,przekraczającym granice braterstwem”148. „Federacja” była synonimem jedności, zrozumiałym dla szerokich grup odbiorców. Stanowiła zjawisko, które ewoluowało i wymagało przygotowania następnych etapów, w żadnym zaś wypadku ich ,,przeskakiwania"149. Schuman był nieufny wobec wszystkich, którzy parli do jak najszybszego powołania unii ${ }^{150}$. Federacja mogła powstać jedynie jako skutek świadomej decyzji narodów Europy, ale do której dojrzały one na skutek długotrwałego procesu. W krótkiej perspektywie „stworzenie Europy” oznaczało dlań ,ustanowienie i intensyfikację koordynacji między państwami wyzwolonymi z egoizmu, ukierunkowanie ich na wspólne dobro ponadnarodowe”, czyli „zgromadzenie państw na rzecz działań pozytywnych, wspólnych i skoordynowanych"151. Mogło to pozwolić na powołanie docelowej jednolitej instytucji władzy eu-

143 J. Łukaszewski, Cel: Europa. Dziewięć esejów o budowniczych jedności europejskiej, Nor sur blanc, Warszawa 2002, s. 139; C.G. Anta, op. cit., s. 64 przyp. 39.

144 R. Schuman, Przemówienie w Moguncji (21 III 1953). A. Muñoz, op. cit., s. 51.

145 Idem, Comment..., s. 8.

146 „Rheinisches Merkur”, 1 I 1953.

${ }^{147}$ R. Schuman, Wystapienie $w$ dziesiąta rocznicę ogłoszenia Planu Schumana, „Paris-Presse”, 17 V 1960.

148 Idem, Dla Europy..., s. 69.

149 Korespondowało to z ówczesnym postrzeganiem terminu „federacja”, który miał charakter nieostry i niejednoznaczny nawet wśród zwolenników jej ostatecznej realizacji. H. Brugmans, La cité européenne. Programme fédéraliste, Le Portulan, Dole 1950; Ch. Durand, Confédération d'Etat et Etat fédéral. Réalisations acquises et perspectives nouvelles, Libraire Maruel Rivière et Cie, Paris 1955.

${ }^{150}$ E. Husson, op. cit., s. 43.

${ }^{151}$ R. Schuman, Comment..., s. 6. 
ropejskiej ${ }^{152}$. Stąd przyjąć musimy, iż Schuman nie chciał zjednoczyć Europy w formie federacji sensu stricto ${ }^{153}$, co uznawał nie tylko za niemożliwe, lecz i niewskazane. „Nie wierzył w to ani tego nie szukał” ${ }^{154}$. Nie wynika z tego bynajmniej, że „Europa ojczyzn” była tą Europą, która leżała mu na sercu. Potwierdza to okoliczność, iż negatywnie odniósł się do gaullistycznego Planu Foucheta ${ }^{155}$.

Rekonstrukcję poglądu Schumana na ostateczny kształt integracji ułatwić może wspomniana już teza o jego neotomistycznych poglądach ${ }^{156}$. Spotkać można pogląd określający go wprost współczesnym odpowiednikiem Akwinaty ${ }^{157}$. Nie znaczyło to oczywiście, że Schuman pragnął przywrócić chrześcijańskie średniowiecze. Chodziło mu raczej o stworzenie czegoś zupełnie nowego w oparciu o założenia chrześcijańskie ${ }^{158}$. Europejczycy ipso facto stanowili moralno-religijną wspólnotę o pozapolitycznym i ponadpozytywnym charakterze, prawdziwą ,jedność w wielości”159. Przez wieki nagromadziły się jednak rozliczne granice dzielące ludzi w sposób całkowicie sprzeczny $\mathrm{z}$ naturą. Schuman był zdania, że nadszedł czas, aby zburzyć te mury ${ }^{160}$. W takim ujęciu mówić można w istocie o „re-integracji”161. Transcendentna wobec podziałów Europy prawnonaturalna jedność nie pozostawała w sprzeczności z partykularnymi tradycjami oraz tożsamościami narodowymi i nie stanowiła dla nich zagrożenia. Te ostatnie winny być utrzymane i to wraz z różnorodnymi formami ich instytucjonalizacji. „Wyższa” wspólnota nie mogła „pochłonąć” narodów, powielając tym błędne założenie omnipotentnego państwa narodowego. Schuman podkreślał, iż narody winny zostać zgromadzone (rassembler), nie zaś zlać się w jedność (fusionner) ${ }^{162}$. Europa powinna stać się wspólnotą narodów, złączonych w jednym wysiłku politycznym i obronnym, skutecznie działającą jednością, świadomą wewnętrznej różnorodności ${ }^{163}$. Zaistnieć winna między nimi więź podobna do tej, jaka funkcjonowała od dawna na płaszczyźnie narodowej ${ }^{164}$. Kryterium był tu poziom solidarności między narodami, którego intensywność miała być porównywalna $\mathrm{z}$ więzią

152 Ibidem, s. 7-8.

${ }^{153}$ R. Schuman, Organization of the Eurpean Defense..., s. 198.

${ }^{154}$ F. Roth, Gtos $w$ dyskusji, [w:] Robert Schuman - Homme d'Etat..., s. 142-143.

${ }^{155}$ L'Europe de Robert Schuman..., s. 71-72.

${ }^{156}$ R. Mougel, op. cit., s. 74-89.

${ }^{157}$ G. Vilaros, Głos w dyskusji, [w:] Robert Schuman-Homme d'Etat..., s. 139.

${ }^{158}$ F. Borella, Gtos w dyskusji, [w:] Robert Schuman-Homme d'Etat..., s. 157.

159 R. Schuman, L'Europe est une communauté spirituelle et culturelle, „Annuaire européen” 1953, s. 17-22.

${ }^{160}$ Idem, Dla Europy..., s. 118.

${ }^{161}$ A. Fimister, Integral Humanism and the Re-Unification of Europe, [w:] Robert Schuman et les Pères..., s. 31-37.

162 R. Schuman, Comment..., s. 5.

163 Idem, Dla Europy..., s. 86.

164 Ibidem, s. 15, 21. 
występującą między regionami tworzącymi jedno państwo ${ }^{165}$. Solidarność wraz z współzależnością ekonomiczną miała zostać sformalizowana poprzez instytucje ponadnarodowe (idea Wspólnego Rynku), które powinny także położyć kres nacjonalizmom i absolutnej suwerenności. Mając na uwadze treść zasady ponadnarodowości, uznać należy, że istotą postulowanych instytucji był ich demokratyczny charakter, wyrażający się w zasadzie głosowania większościowego. W rezultacie powstałaby struktura, wzorem dla której nie było ani Cesarstwo czy Rzesza, ani Święte Przymierze ${ }^{166}$, ani państwa federalne ${ }^{167}$. Byłaby to wspólnota sui generis: une Cité européenne future ${ }^{168}$.

IV. Schuman, jako francuski minister, miał świadomość kluczowej roli Francji w Europie i nie zapominał o realizacji interesów narodowych. Jednocześnie rozumiał, że można je realizować pełniej w szerszych europejskich ramach oraz warunkach pokoju i jedności ${ }^{169}$. Przy słabości państwa najlepszy sposób służenia własnemu krajowi stanowiło zapewnienie możliwości współpracy z innymi narodami. „Nie służymy narodowemu interesowi przez lękliwe i egoistyczne odgradzanie się od innych, czynimy to raczej poszukując ugodowego porozumienia i szeroko zakrojonej współpracy"170. Interes narodowy wymagał wyjścia poza ograniczenia środków narodowych i odpowiadających im koncepcji politycznych. Służba szerszej wspólnocie nie była w żadnym wypadku zaprzeczeniem lojalności wobec własnej wspólnoty narodowej, jeśli tylko zachodziła w warunkach niezależności i pokoju ${ }^{171}$. Takie założenia godziły interesy narodowe z uniwersalnymi ${ }^{172}$. Stąd teza A. Marszałka, że Schuman łączył Kantowską ideę pokoju z obiektywnym charakterem państwa ${ }^{173}$. Ponadnarodowość opierała się na narodowości i nie prowadziła do odrzucenia chwalebnej przeszłości, lecz wyzwalała nową energię z narodu za sprawą wprzęgnięcia go w służbę wspólnego interesu. Instytucja ponadnarodowa wyrastała z narodu i wykracza poza niego, zapewniając mu bardziej wzniosłe i szersze pole działania ${ }^{174}$. To, co narodowe miało rozwinąć się w ponadnarodowe ${ }^{175}$, bez najmniejszego uszczerbku dla wartości narodowych ${ }^{176}$. Europa nie miała więc zaistnieć ani kosztem, ani zamiast państw, lecz w oparciu

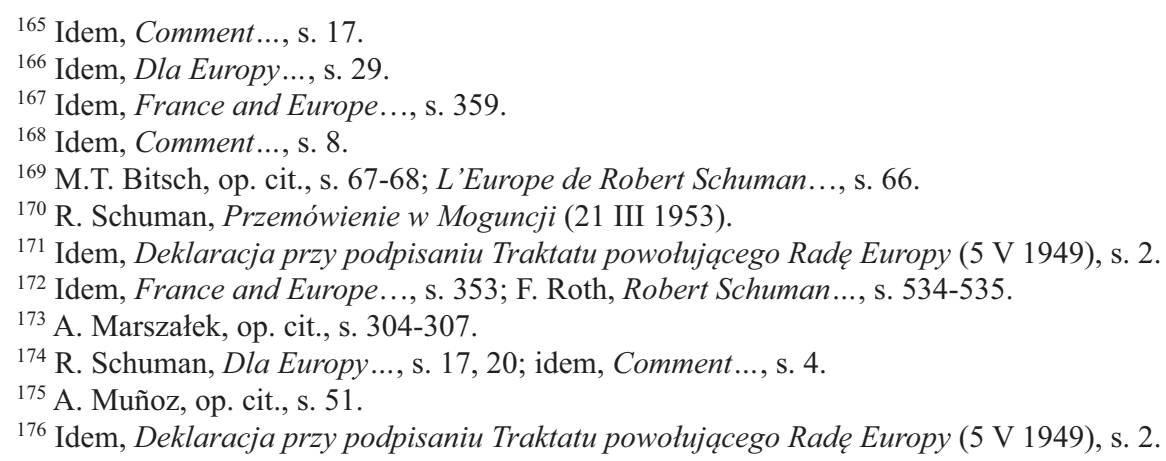


o płaszczyznę państwowo-narodową struktury. Pozwala to kreślić przyszły kształt Europy jako strukturę organiczną dla jej narodów.

Wbrew zarzutom Schuman nigdy nie chciał dokonać rozkładu państwa narodowego. Przeciwnie, zawzięcie go bronił i sumiennie mu służył ${ }^{177}$. „Życie swoje poświęcił państwu, nie doktrynie czy partii" ${ }^{178}$. Państwa i granice musiały dla niego istnieć. „Nie można myśleć o ich przekreśleniu”179. Nie należało obalać państw ani wywłaszczać ich z zasadniczych uprawnień, ale adaptować je do nowej epoki w warunkach wzajemnej współpracy ${ }^{180}$. Państwa miały zostać wkomponowane w szerszą wspólnotę, która odzwierciedlałaby funkcjonujący wśród nich stopień solidarności oraz zakres dobra wspólnego i służyłaby ich urzeczywistnianiu. „Państwa europejskie nie powinny sądzić, że mogą zrezygnować ze swej narodowo-państwowej tożsamości. Zostaną utrzymane jako suwerenne państwa i będą się rozwijać tak, jak to czyni jednostka lub rodzina w ramach państwa"181. Granice zostaną tylko pozbawione swego sztywnego czy wrogiego charakteru, za sprawą czego staną się liniami kontaktu ${ }^{182}$. Zasada wspólnotowa była przykładem idées forces: była odważna, płodna, dynamiczna, porównywalna $\mathrm{z}$ odkryciem naukowym zapewniającym realizację potrzeb w warunkach nowej epoki ${ }^{183}$.

Koniecznym warunkiem realizacji powyższego było trwałe ograniczenie suwerenności dokonywane na zasadach pełnej wzajemności. Ograniczenie przyjmowało postać dwojaką: transferu części władzy na instytucje ponadnarodowe oraz akceptacji większościowego trybu podejmowania decyzji. Jego dokonanie nie było celem ostatecznym, ale środkiem bez alternatywy dla realizacji doniosłych celów: ,,przezwyciężenia narodowych egoizmów, antagonizmów i zawężonego postrzegania własnych czynów"184.

\section{THE CONCEPT OF STATE SOVEREIGNTY \\ IN ROBERT SCHUMAN'S IDEA OF INTEGRATION}

\section{Summary}

The paper discusses a key element in Robert Schuman's European idea, namely his view on state sovereignty. Resting on Thomist and personalist assumptions, Schu-

${ }^{177}$ F. Roth, Robert Schuman ..., s. 533.

${ }^{178}$ G. Elgozy, Robert Schuman, la discretion au pouvoir, „Le Figaro”, 12 I 1987.

${ }^{179}$ R. Schuman, Dla Europy..., s. 17-18.

${ }^{180}$ J. Łukaszewski, op. cit., s. 128.

${ }^{181}$ R. Schuman, Przemówienie w Moguncji (21 III 1953).

${ }^{182}$ Idem, Dla Europy..., s. 23.

${ }^{183}$ Idem, Origines ..., s. 14.

${ }^{184}$ Idem, Przemówienie przed Zgromadzeniem Rady Europy (10 VIII 1950), s. 2. 
man saw nations and states as the immanent elements of European reality. This, however, did not mean that he fully approved of the paradigm of sovereignty, prevailing at that time, as absolute power. He considered it a source of threats and dangerous claims, as much unattainable as misguided. He clearly saw a disparity between the theory of absolute sovereignty and the actual declining potential of states at that time. A measure to alleviate the hardships of post-war Europe, cooperation to be initiated among its nations was meant not as a classic inter-governmental cooperation but rather as an 'integration' or a form of cooperation involving a restriction of sovereignty. A prerequisite to achieve this, solidarity (solidarité du fait) led to the rise of an actual community. This understanding of solidarity and community was related to the category of common good placed above any particular national interest. Initially, Schuman was quite sceptical about the idea of supranationality. Finally, he accepted it but forged it to mean the principle of arriving at decisions by a majority vote at the forum of international organizations. Any recognition of decisions arrived at in this fashion entailed the necessity to restrict sovereignty. All these elements made up the constitutive characteristics of a new institution of cooperation to be known as 'community'. It was not to serve the pursuance of immediate interests but rather to foster common good, which made it last. The gravity of tasks required every state to make an appropriate contribution in the form of a fragment of its sovereignty. The potential scope of matters left to the care of the community was very broad and encompassed the economy, politics and defence. The core of the community was to be a supranational body and three other institutions: an assembly providing democratic accountability, a court of justice guarding the law, and a council maintaining contact with the national plane. The ultimate goal of integration was a peculiar 'federation', the rise of which by no means meant the elimination of the nation, state or sovereignty. On the contrary: the new structure was to grow from the national plane and form with it an organic whole. A fundamental prerequisite to its construction was, however, a permanent restriction of state sovereignty.

\section{VISION DE LA SOUVERAINETÉ DE L'ÉTAT DANS LA CONCEPTION DE L'INTÉGRATION DE ROBERT SCHUMAN}

\section{Résumé}

L'article traite de l'un des éléments clés de la conception européenne de Robert Schuman, qui est l'idée de la souveraineté de l'État. Schuman est parti des principes du thomisme et du personnalisme. Il considère les nations et les États comme les éléments immanents de la réalité européenne. Cela ne signifie cependant pas qu'il affirme totalement le paradigme de la souveraineté de l'époque, comme le pouvoir absolu. Selon lui, cette dernière est source des dangers et des revendications inatteignables en pratique et très dangereuses à la fois. Schuman voit en outre un décalage clair entre la théorie de la souveraineté absolue et le potentiel réel, défaillant, 
des États de l'époque. Le moyen permettant de remédier aux difficultés de l'Europe d'après-guerre était la coopération entre les nations qu'il fallait initier. Il ne s'agit toutefois pas d'une coopération classique, intergouvernementale mais " d'une intégration », c'est-à-dire d'une forme de synergie prévoyant une souveraineté limitée. La condition matérielle permettant de le réaliser était la solidarité du fait qui conduisait à la naissance d'une réelle communauté. Avec la solidarité et la communauté perçues ainsi est liée la catégorie du bien commun, placé au-delà de tout intérêt particulier des nations. Tout au début, Schuman reste assez sceptique quant aux idées de la supranationalité. Il finira toutefois par l'accepter mais elle revêtira chez lui le sens de la règle selon laquelle les décisions sont prises à la majorité par les organisations internationales. Admettre les décisions prises ainsi correspond à la nécessité de la limitation de la souveraineté. Tous ces éléments font partie des traits constitutifs de la nouvelle institution ayant pour objectif une coopération et qui est « la communauté ». La communauté sert non pas à la réalisation des intérêts provisoires mais du bien commun, ce qui détermine sa pérennité. L'importance des missions à accomplir demandait à chaque État d'apporter une contribution proportionnée, soit un fragment de leur souveraineté respective. En ce qui concerne l'étendue potentielle des matières confiées à la communauté, elle est très large et contient l'économie, la politique et la défense. La colonne vertébrale de la communauté est un organisme supranational avec trois autres institutions : l'Assemblée assurant un contôle démocratique, le Tribunal gardien du droit et le Conseil permettant de garder le contact avec le niveau national. L'objectif ultime de l'intégration était la création « d'une fédération » spécifique dont la naissance ne signifiait en aucun cas l'élimination de la nation, de l'État ni celle de la souveraineté. Au contraire, la nouvelle structure devait naître à partir du niveau national, constituant avec ce dernier un ensemble limité. Néanmoins, afin de le réaliser, la condition principale à remplir restait la limitation permanente de la souveraineté de l'État. 